\title{
Views from the margins: Theorising the experiences of black working-class students in academic development in a historically white South African university
}

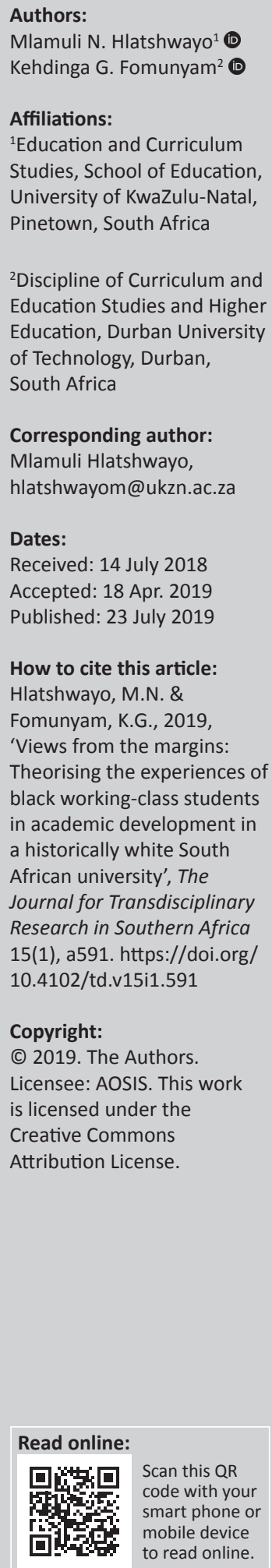

A significant amount of South African literature on academic development often focuses on the ideological and theoretical shifts that have occurred within the academic development field across different periods in the country - tracing different phases within the field, broadly termed, 'academic support', 'academic development' and 'higher education development'. One of the gaps that have been identified in this literature is often the silence regarding the experiences of the black students themselves in academic development, and to what extent being in the programme has made a difference to their university experiences. This article attempts to fill this gap by critically exploring and theorising the complex experiences of black working-class South African students in an academic development programme in a historically white higher education institution. To effectively make sense of their experiences, French philosopher Pierre Bourdieu's theory on capital was employed in this article. Participants were purposely recruited using snowball sampling and 32 black working-class students participated in the study. The findings of this study suggest that academic development in a historically white university is a complex field of forces that require further critical interrogation and theorisation. Students' experiences of academic development are often complex and at times contradictory with some seeing the value of the programme, and others rejecting it and looking at it as an extension of their marginality in a historically white higher education institution.

Keywords: Academic development; higher education; black students; historically white university; Bourdieu; capital.

\section{Introduction}

The emergence of the 2015-2016 student movement in South African higher education was a critical moment in the South African higher education landscape. Critical issues that students brought to the forefront include, but are not limited to, the urgent demands for decolonisation or Africanisation of higher education (hereafter referred to as HE) system, the issues of curricular, or what Jansen and Motala (2017) refer to, as 'curriculum as an institution', the transformation of pedagogical practices of teaching and learning, the re-presentation of blackness and black $^{1}$ identities in the physical spaces and architecture of the institution themselves and others (see Badat 2016; Muller 2014; Prinsloo 2016). We should note that since the collapse of the apartheid regime and the coming in of the new democratic dispensation, historically black universities have never really transitioned to the 'post' in terms of stability as they have been consistently mired in violence, protests and disruptions in the academic programme (see, e.g. Badat 2009, 2016). Other issues have ranged from being placed under administration, systemic corruption, staff workers' protests, labour bargaining issues and others (Badat 2009; Fourie 1999; Marx 1998).

We have specifically chosen to look at the marginalised experiences of black students in a historically white South African university as these are the universities that, the literature suggests: (1) have come under intensive scrutiny in terms of the above demands for transformation and decolonisation, and that the (2) black working-class students in these institutions are often marginalised, struggle to adjust to the academic and social demands of the institution (see, e.g. Sennett et al. 2003; Vincent 2008; Vincent \& Hlatshwayo 2018). However, lacking in this literature is the role that academic development (hereafter referred to as AD) plays in helping black working-class students negotiate the challenge of HE in a historically

1.Throughout this article, the term 'Black' will be used to refer to Black South Africans. These terms are a result of racial categories established under apartheid laws and continue to be significant socio-economic and political markers that have real implications in South Africa. 
white university in South Africa. It is against the aboveidentified gaps that this article seeks to contribute to. In addition, one of the fields that do not feature prominently in these calls for transformation and decolonisation is the $\mathrm{AD}$ or as they are often referred to in other universities, 'extended studies programme', 'foundation phase', 'access programmes'.

The current study explores the students' experiences in these programmes and to what extent they are able to negotiate their marginality in university and cope both socially and academically. The absence of the ADs in the broader calls for critical reflection and decolonisation ${ }^{2}$ ensures that we hope to continue to shine a spotlight on the field of ADs in South Africa, and the critical role they play in bridging the gap between HE and public schooling.

This article is divided into two sections. Firstly, we begin by arguing that before looking at ADs, it is important that we contextualise and historicise the emergence of the field of $\mathrm{AD}$ in South African HE, and to what extent it differs from its international counterparts. Secondly, we then locate the emergence of ADs to the historically fragmented South African HE, shedding a spotlight on the institutional differentiation that was happening between historically black universities and historically white universities, and to what extent the social dislocation, marginality, pain and alienation experienced currently by black working-class students in the AD programme could be located and shaped by this history. This section will end with bringing in the theoretical and methodological lenses of the study, that is, introducing Bourdieu in arguing that at the heart of Bourdieu's theoretical contributions is his commitment at exposing $\mathrm{HE}$ as playing a significant role in reproducing inequality in society. His notions of habitus, existing within a particular field (economic, social and cultural), will be useful in looking at $\mathrm{AD}$ as a field in a historically white university and the experiences of black working-class students in it as they compete for symbolic capital that will allow them to negotiate their marginality and succeed in HE (Bourdieu 2003, 2011; Naidoo 2004).

The second section of this article will combine both the data analysis and the findings in offering theoretical discussions on the emerging and critical experiences of black workingclass students, as they navigate, struggle, succeed, fail and persist in the AD programme in a historically white South African university. We end the article with recommendations and suggestion both at the theoretical level and practically on how to improve black working-class conditions in a historically white university in general and in strengthening the critical work of the AD programme in particular.

We now turn to historicising AD programmes and institutional differentiation in the South African HE landscape.

\footnotetext{
2.We note, in particular, the insightful work by Vorster and Quinn (2017) in looking at the field $A$ AD and the decolonial turn', that is, looking at the (2013) in looking at the field of AD and the 'decolonial turn', that is, looking at the colonial forms of domination, control and cultures that continue beyond the end of colonialism in AD programmes. However, this work looks specifically at academic staff development, and not on the academic student development, as is our focus in this article.
}

Part 1: Mapping the context Academic development in South African higher education: Phases, discourses

The field of AD, or what Boughey (2007:2) terms the 'academic development movement', can be traced between the three critical phases: 'academic support', 'academic development' and 'higher education development'. ${ }^{3}$ The first phase, the academic support, dates back to the early initiatives that intended to provide support to the small and emerging group of black students who were entering historically white liberal institutions in the early 1980s as a result of the apartheid regime's relaxation of the laws (Boughey 2007; Pavlich \& Orkin 1993).

The second phase, the academic development, beginning in the early 1990s, was characterised by the ideological shift whereby $\mathrm{AD}$ was now focusing on preparing itself and its teaching and learning practices for the expected proliferating 'demographic revolution's in student enrolments that was happening in $\mathrm{HE}$ with the black majority (Akoojee \& Nkomo 2007; Badat 2009; Boughey 2003, 2007). Rather than centring student support, AD was focusing on the development of teaching and learning material and curricular developments that would meet the needs of the incoming black majority. In the third and final phase, the higher education development focuses on the social construction of offices and support systems in HE.

It should be noted that the above phases of AD should not be treated as separate 'epistemic breaks' (Foucault 2013) that are designed to demarcate continuity and discontinuity in the literature. Rather, and this forms one of our key arguments in the article, these discourses serve as careful analytical frames that show the contested nature of the field of AD in the South African HE landscape. This is particularly seen in how, as recent as 2014, Dhunpath and Vithal (2014) argue against the still prevalent notions of 'student underpreparedness' found in the first phase of AD - in how HE institutions in South Africa attempt to frustrate transformation through looking at students as 'decontextualized learners' (McKenna 2004) who need to be prescribed with 'language', 'literacy skills', 'computer skills' and others, instead of looking at the institution itself as needing to transform. Thus, as our findings and discussion will show in how students' experiences of $\mathrm{AD}$ in a historically white university are complex, contradictory and, at times, seem to reflect earlier debates on $\mathrm{AD}$ as found in the first and second phases, respectively.

It is generally accepted that the negotiated settlement which brought about the African National Congress (ANC) into power in the early 1990s had a profound impact on the policy

3.These phases do not represent clear well-ordered 'epistemic boundaries' in the field of AD. Rather, it represents the different shifts and patterns in the literature. In reality, the field is much messier and complex, and transcends these boundaries that are 'drawn' here (Dhunpath \& Vithal 2014).

4.It should be noted that this 'demographic revolution' that was happening in South African higher education beginning of the early 1990 s was largely occurring in the historically white universities rather than in historically black universities (Jansen 2004). Enrolment rates and demand for HE in historically black universities largely remained the same in terms of race and class. 
and discourses on AD (see Boughey 2007; Kraak 2001; Oldfield 2001). This was seen in how before the ANC came into power, the then discourse of the liberation movement was largely socialist and left-leaning. However post-1994, a new discourse remerged that could best be characterised 'neoliberal' and 'social democratic', which resulted in the introduction of stringent macroeconomic framework and a general acceptance of the role that the market plays in HE educational policy. Academic development was largely implicated in all these debates as was seen in the curriculum development, delivery and the management of HE institutions (Boughey 2007).

We provided the above background because it is critical to understand the contested history of AD in South African HE. We cannot foreground historically white institutions and the experiences of black students, without first looking at what is $\mathrm{AD}$, where it comes from and the different discourses that continue to shape its work. We now turn to looking at a brief and yet fragmented history of South African HE and the emergence of the historically white universities as a deeply contested space in HE.

\section{Institutional differentiation: On the structural inequality of South African higher education}

South African HE is profoundly shaped and structurally influenced by the history of colonisation and apartheid (Akoojee \& Nkomo 2007; Badat \& Sayed 2014). The apartheid regime's racial segregation and colonial assumptions of white supremacy were also reinforced and implemented in HE institutions, as the institutions were seen as intellectual, epistemic and linguistic tools necessary for the needs of the apartheid state. During the apartheid period, we had, firstly, those in the dominant tier, then we had those who were in the intermediary tier and finally, we had universities that were in the subordinate tier (Naidoo 2004).

In the dominant tier, these were the universities that were established under the colonial period and whose primary function was the extension of the English values, ethics and beliefs in the colony. When the apartheid regime introduced stringent HE laws in 1959, these universities became exclusively for the white students. These universities were, and to a large extent still continue to be, research intensive and enjoy favourable international reputations and ranking, coupled with well-established infrastructures. Our current study is located in one of the universities on this tier in looking at the experiences of black working-class students in negotiating their marginality in the $\mathrm{AD}$ programme. The history of these universities being exclusively for white students, and the classism and elitism that often characterises such institution, offers an opportunity to look at those on the margins of this university, that is, those who could be seen as 'space invaders' (Puwar 2004), on their experiences in the AD programme, and to what extent the AD could be enabling them to successfully cope both socially and academically in the dominant tier.
In the intermediary tier, we had the Afrikaans-speaking universities that were established with the purpose of countering the hegemonic influences of the dominant tier universities, and to serve as a benefit to the Afrikaans community. The primary function of these universities in this tier was to serve as a socio-economic and linguistic resource in producing and maintaining Afrikaner national identity, together with the production of the Afrikaner elites who would play a critical role in the apartheid state. In the third and final tier, we had the subordinate tier. These universities were characterised by, and to some extent still continue to experience poor funding, lack of adequate infrastructural development, chronic and systemic protest action on campus and social upheaval.

It is on the above institutional differentiation and structural inequality in the South African HE landscape that we chose to foreground the experiences of black working students in a historically white university in the AD programme. The fragmented and contested history of South African HE terrain offers us an exciting opportunity to look at the extent to which history plays a role in their marginality, isolation and lack of throughput and retention of black working-class students in such spaces. We now turn to outlining the theoretical and methodological lenses that were adopted in this article.

\section{Theoretical lenses: Bringing in Bourdieu to South African higher education}

At the heart of Bourdieu's theoretical contributions is his commitment to expose $\mathrm{HE}$ as a powerful contributor to maintaining and reproducing social inequality (Bourdieu 1993; Naidoo 2004). This focus has led to the significant theoretical and empirical contributions to our sociological understanding of the relationship between universities and society (Naidoo 2004). Naidoo (2004) argues that this overreaching focus and commitment have resulted in the introduction of key conceptual tools of 'field', 'capital' and 'habitus'. These concepts relate and function with one another. In this article, two (capital and habitus) of these three conceptual lenses are engaged to theorise the experiences of black working-class students in AD. Before critically discussing the notion of capital, it is important to first outline field because for Bourdieu, the logic of capital operates within the domain of a particular field (Bourdieu 1993; Naidoo 2004; Shawa 2015).

Drawing on Weber's sociology of religion, Bourdieu conceptualises society as differentiated into a number of semi-autonomous fields (such as the fields of economics, religion, cultural production and others), which are all governed by their own 'rules of the game', with their own economies of exchange, rewards and sanction systems (Benson 1999; Bourdieu \& Johnson 1993). Bourdieu and Wacquant (1974) conceive a field as a:

... network or configuration, or objective relations between positions... these positions are objectively defined in their existence and in the determinations they impose upon their occupants, agents or institutions...as well as their objective relations to other positions. (p. 97) 
In other words, a field can be said to refer to a 'structured space of positions in which the positions and their interactions are determined by the distribution of different kinds of resources or capitals' (Ihlen 2005:493). A field should thus be understood as a space in which people compete for resources with one another (Shawa 2015). These binaries and oppositions could be said to be reflections and refractions of the overall class divisions in society, these seen between the dominant and the dominated. We also see the split within the dominant class, between the dominant economic and political power on the one hand, and the dominated cultural power on the other hand (Benson 1999:464). This means that society is structured around basic oppositions between the 'economic' and 'cultural power', with the latter being regarded to be weaker, but, as suggested by Weber, influential to the extent that it legitimates and masks economic wealth.

Using Bourdieu's concept of the field in this article enables the conceptualisation of a historically white HE institution and ADs to be seen as a field that compromises competing actors who have oppositional interests, and all competing for symbolic resources. This means that ADs in historically white HE institution could be conceived as a relatively autonomous sphere of activities that operates according to its own rules and logic (Benson 1999; Giloi 2015; Maton 2013).

As mentioned above, a field comprises of agents who are relationally positioned and who attempt to maximise their position in the field in the struggle over resources (i.e. capital) that confer status and authority (Arbee 2012:37-38). This means that in the field there is economic, cultural and social capital. Economic capital refers to money, that is, economic resources that one has access to and possesses (Bourdieu 2011). Cultural capital for Bourdieu exists in three key forms: firstly, it exists in the embodied state, that is, the personal dispositions, habits, tastes and others. Secondly, they exist through cultural goods, that is, the books, theories, music and others that one listens to, consumes and continues to accept and legitimate. Thirdly, cultural capital exists through the institutionalised state, that is, the schooling, qualifications, association and others that confer cultural capital and belong to the field (Bourdieu 2011).

Social capital refers to the 'aggregate of the actual or potential resources which are linked to possession of a durable network of more or less institutionalized relationships of mutual acquaintance and recognition' (Bourdieu 2011:83). This is seen in how social capital refers to the networks, connections and associations, both formal and informal, an agent has and belongs to. It should be emphasised that in the Bourdieuan sense, social capital is the only capital if an agent not only has access to the networks and connections, but can actually withdraw from them (Bourdieu 2011; Bourdieu \& Johnson 1993; Putnam 1995, 2000). Simply put, knowing someone alone may constitute the social, but not the capital. Social capital denotes the ability to withdraw from the connection through the ability to gain something whether it is information, employment, advice or any 'withdrawal' that may be required.

The relations between the agents and their contestations over the resources give the structure of the field. Both the type of capital (i.e. economic, cultural, social) and the amount of capital are significant for conferring status within the field. This means that it is not how much capital you have in the field, but rather whether you have the right type of capital (Arbee 2012:38-39). Thus, the struggles in the field that black working-class students find themselves in and need to negotiate in $\mathrm{AD}$ are not only about the amassing of more capital, but also about the type of capital that should be considered as the 'dominant measure of achievement' in the field (Maton 2005).

Habitus can be understood as 'the semi-conscious dispositions that people, particularly in their early lives, acquire through social or material interaction with their habitat and through the social relations in their part of the social field' (Fairclough, Jessop \& Sayer 2002:9). Bourdieu defines habitus as a 'set of assumptions, habits, taken-for-granted ideas and ways of being that are vehicles through which agents engage with, understand and move on through the world' (Bourdieu 1977 in Bebbington 2007:155-156). This means that for Bourdieu, habitus explains our beliefs, thoughts, tastes and interests that tend to influence our understanding of the world. This is seen in how habitus is formed primarily through socialisation through family, schooling, culture and the milieu of education (Bourdieu 2011; Bourdieu \& Johnson 1993; Bourdieu \& Wacquant 1974).

In relation to this article, habitus offers an opportunity to look at the dispositions, beliefs, thoughts and behaviour of black working-class students in the $\mathrm{AD}$ programme and how they use their dispositions, tastes, values, beliefs and others to negotiate their marginality and succeed in HE. While we employ Bourdieu's conception of AD as a field of competing forces over symbolic capital, it should also be noted that within the field of AD in general and historically white universities in particular, academics and university management could be re-conceptualised as agents operating within such structures that continue to look at black working-class students as a 'problem people' (Du Bois 2008). As mentioned, this has resulted in AD discourses that have adopted an approach of looking at student as 'decontextualized learners' (McKenna 2004) who need to be 'fixed', either with the 'correct' language, literacy practices, institutional culture or others. Thus, our conceptual discussions of $\mathrm{AD}$ as a Bourdieuan field of forces do not deemphasise the importance that agents themselves in historically white universities and in the AD programme play, in constructing, maintaining and, at times, interrupting the marginality that black students experience.

The outlined conceptual and theoretical tools from Bourdieu will be employed in the study, to theorise the complex experiences of black working-class students in $\mathrm{AD}$. 


\section{Research design and methodology}

In this article, we employed qualitative research methods of data generation and analysis, located within the interpretivist paradigm. Palys (2008:xxix) suggests that qualitative research is designed to 'explore the human elements of a given topic' in allowing us to see how 'individuals see and experience the world'. This means that qualitative research assumes that individuals play a significant role in the social construction of their own social reality, and that the role of researchers is thus to interpret the various ways in which individuals make sense of their reality. Operating within the interpretivist paradigm, the central aim of this article is to attempt to understand the complex experiences of black working-class South African students in negotiating AD that ranges from institutional culture, language, curriculum access and success, among others, in a historically white HE institution. Rather than focusing only on interpreting their success or social experiences, this article goes a step further in looking specifically at the interesting ways in which black workingclass students negotiate this marginality, which enables them to 'survive' the HE terrain. Neuman (2010:102) suggests that interpretivism focuses on the need to understand social reality and the various ways in which people construct meaning-making in their own settings. The use of qualitative research methods in this article provided the necessary insight into black working-class students as they construct their experiences and the strategies they employ in negotiating their entry and academic success in a historically white institution (HWI) historically white university

Faugier and Sargeant (1997:792) argue that snowballing techniques are particularly useful for hidden populations, or at least when attempting to research around a sensitive topic. The research on black working-class students and some of the challenges they face in historically white universitites in general and in the AD in particular is a sensitive topic as it exposes the socio-economic backgrounds that they come from and some of the difficulties they have to overcome.

Semi-structured interviews were employed in an effort to gain in-depth understanding of the lives and experiences of research participants. Seidman (2006:9) argues that the use of in-depth interviews helps the researcher understand not only the lived experiences of the other people, but it also enables him or her to understand how those people make meaning of their lives. Semi-structured interviews enabled providing a platform to understand, interpret and theorise black workingclass students' experiences in AD. We now turn to the second part of this article, where we combine both the data analysis and the findings, in offering theoretical discussions on the emerging and critical experiences of black working-class students, as they navigate, struggle, succeed, fail and persist in the AD programme in a historically white university.

\section{Ethical consideration}

All ethical considerations were adhered to and the study did obtain the necessary ethical permission from Rhodes University's Humanities Research higher degrees committee.

\section{Part 2: Data analysis and discussion}

The data generated were coded and categorised in line with the lens theorised in the early parts of this article. The two lenses used in this analysis are capital and habitus. This section of the article theorises the experiences of students and uses the theoretical lens to make meaning of the experiences. Capital, as already pointed out, can be understood from three different perspectives: cultural, social and economic capital. And because habitus is the strategy-generating principle enabling agents to cope with unforeseen and everchanging situations, it becomes critical to understand how habitus in line with capital can provide direction to student experiences. Capital and habitus therefore inform this part of the article.

\section{The development of capital}

O'Brien and O'Fathaigh (2005) argue that capital is a gauge of a student's position in the social field, seeing capital as a strategic resource in achieving or maintaining position in a field. Economic capital refers to material assets and income available to a student. Social capital refers to the student's capability to use social connections (informal and institutionalised, such as belonging to associations) as a potential pool of resources to act and achieve his or her goals or to improve a position in a social field. Cultural capital refers to both formal education and the embodied skills and knowledge. If cultural capital is primarily an individual's feature or capacity, social capital is shared among individuals. The combination of these three forms of capital denotes social prestige and dignity associated with a certain position. Harker, Mahar and Wilkes (2016) add that when students shift or switch from one social field to another (leaving home or local community to the university as is the case with most of the students), they may experience difficulties transferring capitals between fields. This was the case for some of the participants of this study as they strived to develop more capital to tap into in the knowledge construction process. Elaborating on this, Bontle points out that:

'My first test in Zoo [Zoology] so I got like 13\%! Do you know how painful it is when you know that in high school you did so well and you come here and your first test you get $13 \%$. Because you didn't hear a thing, Okay they were talking about dinosaurs, people who are from backgrounds where you exposed to world war stuff then you would get it. I didn't get it.' (Bontle, black female)

In the above quotation, Bontle reflects in her first test in Zoology, she got a mark of $13 \%$. For her, this mark signals an academic disconnection between her performances in school where she was doing well academically and at the university where she was initially struggling. This is seen in how she lacks what may be seen as the right kind of capital in having access to the curriculum. Decolonial scholars have offered a critique at this 'right kind' of capital in how it presents itself as an 'adjustment' challenge and only needs students to adapt. However, it tends to do two things: firstly, it mainly seeks to posit on students as 'deficient' and needing to be 'fixed' to 
cope with the challenges of HE. Secondly, it removes the epistemic and institutional responsibilities of transformation away from the institution itself and passes it to students.

Speaking about her experiences in the $\mathrm{AD}$ programme, Bontle comments that:

\begin{abstract}
'It's nice [mentoring]! I think it's really nice. Because we not only speaking about school life, we also speak about life, they didn't cope with a lot of, you know like workload. We used to it by now, we like okay bring it on. And now they're not handling it well. So I was just giving them pointers here and there because they are not attending some of the sessions so I only have a few girls instead of everyone. And then we also have the WhatsApp group, we communicate then people just come in, and see what can we do with us and then some of the girls have the same degrees, if they need help, they go to the same tutor together. Like, I help them when I can and if they do ask for help. But I'm like, my door is always open. But it's a great experience, I see them grow to be being varsity girls. And, that's nice to watch. I think it's really nice. I love mentoring people. And I like being like motivational kind of speaker because I think, for the things that I have went through, and the knowledge that I've acquired now like everything, it's easier to do that. To the first years, and to anyone actually to be a motivational speaker kind of person to them. So yeah it's really nice seeing them and we laugh through everything.' (Bontle, black female)
\end{abstract}

In the above quotation, Bontle reflects Bourdieu's notion of social capital in how her previous experiences of negotiating marginality in a historically white university, she sees herself as a useful network for those other students who are coming in and still struggling to adjust to the demands of HE.

Shammas and Sandberg (2016) argue that capital is an asset, which enables holders to mobilise or develop competencies in education, intellect, style of speech, dress or physical appearance. The mentoring programmes become a strand for the development of capital, which in itself becomes social assets (education, intellect, style of speech and dress, etc.) in the hands of the students used in the construction and reconstruction of knowledge as they make their academic progress. This is supported by Yang (2014) who argues that capital functions as a social relation within an economy of practices (in this case the university), and comprises all of the material and symbolic artefacts. This process of AD becomes critical in the academic progress and progression of black working-class students as programmes like mentoring aims at assisting them in navigating the HE terrain.

One of the strengths of the different forms of capital is not only how they influence one another, but actually how they produce each other (Bourdieu 1984, 2003, 2011). This too is seen in how black working-class students in the AD programme tend to rely on other external connections and networks to be able to navigate the financial pressures of being in HE. Lungile, for instance, reflects the international literature on how first-generation black students tend to have one or more jobs at university to financially survive the challenges - he comments that:
'I've done quite a number of jobs, I used to be a news reporter at Radio Grahamstown, I wrote for Grocott's Mail, I wrote for Activate, I've been a bar tender at Oldies but in terms of being employed by the university no ... I got it via Mathew Mphahlwa, and he was doing his final year in journalism but towards the end of the year we used to sit together for seconds (meals), I would do voice overs because he used to give a story and I would Google it and write something about it then go on air and read it out loud but I think he ended up having problems with the manager of Radio Grahamstown he stopped reading those news and I actually went to the manager to ask for the job of being a news presenter and I was given it ... Mathew is from Mthatha as well, he used to sit in the same table in the dining hall we arrived the same time and we all ate seconds together that's how it all started but as time went by we started discussing other issues.' (Lungile, black male)

The networks created and experiences gleaned from these engagements gave the student the opportunity to develop capital at all three levels and be able to improve themselves within the HE sector. Yang (2014) confirms this by adding that the economic capital can easily be converted to cultural and social capital. Emphasising the network between these three forms of capital and how they mutually enforce one another, Lungile continues:

'I heard about it [university] at a career fair we were at school and we collected the applications forms from the various institutions, I filled in the form and consulted my teacher Mr. Adams who was teaching me mathematical literacy in high school and we were a bit close and we would sit together even through lunch time, he used to give me his lunch box and stuff he used to call me when he needed his car washed and I would actually do it for him, he's there one who assisted when it came to proof reading and editing the essay which one had to fill in because when I went back at home, they couldn't assist that much because they don't have that experience of university of what was necessary to include and not include on the application form and stuff I mostly relied on Mr. Adams for advice on what exactly to include in the essay.' (Lungile, black male)

In the above quotations, Lungile comments on the challenges of receiving career guidance advice in a predominately township or rural school. Bourdieu (2003) argues that cultural capital is especially transferred by family and education, be it formal or informal and may be institutionalised or engaged with nominally like group meetings, mentoring programmes, extended programmes, foundation programmes, among others. Capital is the primary cause for educational status and relative positions within the educational ladder. Levina and Arriaga (2014) add that cultural capital can exist or be incorporated in three forms: the embodied, the objectified and the institutionalised state, of which objectified and the institutionalised indicate the possession of cultural artefacts and educational credentials. The embodied state is critical to an individual because it involves an ability to decipher the 'cultural codes' that are composed of material cultural objects, for example, writings, paintings and monuments. Academic development in this context involves the embodied, objectified and institutionalised as both the 
university and the students work together for better student experiences and the enhancement of academic performance.

Acar (2011) and O'Brien and O'Fathaigh (2005), adding to this, argue that the

... differences in student or academic success can be attributed to different levels of existing social capital which is produced in the networks and connections of families that the school serves ... social capital supports success and education in the form of the disciplinary and academic climate at school, and also the cultural norms and values that motivate students to achieve higher goals. (p. 458)

In the absence of economic and cultural capital, they resort to diligence and social capital networks to 'make up' this stock and ensure that they navigate and succeed in HE. It is important to note that social capital is not the merely knowing and being familiar with someone one needs to actually have access to the network and also the option to withdraw from it.

The importance of mutual networks and connections for black working-class students' success in a historically white university cannot be overemphasised. Lundi and Mariah, below, comment on how forming study groups and having mutual friends around, who could have access to and give clarity regarding the study material, made a significant difference in their university life and success:

'We were in study groups. By study groups I do not necessarily mean that people will sit together and study together. What I mean is you are at the library, I am at the library. Me seeing you there sort of also motivates me to study... I felt like the people in the library had read all the books in the library and I hadn't so I had to catch up so that for me is why I kept on reading stuff. I read and study continuously. By talking to these people once in a while, I learn a lot and know that I must keep studying if I must succeed.' (Lundi, black male)

Another participant, Mariah, added that:

'I found it [university] very intense. And to an extent that I couldn't stop working. I remember this so many times within the first term that I used to just cry and called home and all of that, especially with the pressure is off things like computer science... but after that I will sit down to study again. So yeah when we go to class I would always be that one who was asking things. Like what is these, and people who did IT [Information Technology] and have been using it would have an understanding of what it is. So they will explain to me and I would continue studying.' (Mariah, black female)

Capital at all levels, be it cultural, social or economic, is vital for AD, and this becomes more critical for black workingclass students in a previously white South African trying to carve a path for themselves.

Capital is a durable system of dispositions and represents one's entirety of intellectual competencies and one's culture or cultivation that presupposes a process of embodiment as it implies a time-intensive labour of inculcation and assimilation (Putnam 2000). Bourdieu and Johnson (1993) add that the acquisition of capital cannot be delegated, but rather the student must work for the acquisition of the same by themselves. The various AD programmes within the university, therefore, and the different infrastructure or offices being put in place to enhance $\mathrm{AD}$, without personal engagement by students' capital, cannot be developed. The relations between the students and their contestations over the resources within the university give structure to their drive to develop capital. Both the type of capital (i.e. economic/cultural/social) and the amount of capital are significant for AD for the student, and this means that it is not how much capital you possess, but rather whether you have the right type of capital at every given point in time (Arbee 2012:38-39).

Thus, the struggles in the field that black working-class students find themselves in and need to negotiate in AD are not only about the amassing of more capital, but also about the type of capital that should be considered as the 'dominant measure of achievement' in the field (Maton 2005).

There were also complexities and differences among the research participants, with some seeing the value of AD in a historically white university as giving them an opportunity to socially construct valuable capital for themselves in negotiating the space, while others felt being part of the programme serve as an epistemic reminder of their marginality and exclusion at university. For instance, one of the participants cautioned us during the interview that $\mathrm{AD}$ is not 'extended studies'; it is a 'BComm family':

'Extended studies, is not extended studies, it's BComm family, which is the F comes from BComm foundation but we say it's BComm family, because I started meeting up with different people from different backgrounds. From different backgrounds. There's like two groups - group A and group B, we started to be very close, as like class. Like we are that close. Sometimes at the soc [Sociology] department they would complain because we making noise, being in a meeting with those people because sort of a, it reminded me of the class that I had in grade 12. In grade 12 I started getting close to the whole class. So like crazy stuff. If you would search for me on YouTube you'd find a video of my class, singing in front of the class, just during the free period. Yeah and then we got here in extended studies which was like [laughing]. It was amazing. I like the people that end up studying to sit with, like different cultures, from different backgrounds and stuff. Cause like before I would normally talk with Xhosa people, am used to Xhosa people, and here we met you with people from different, Zulus, Tswana, even Rahim, he normally called himself Kindian. His mother is a Coloured and his father is an Indian. So he called himself Kindian [laughing]. I became kinda close with him to what's the end of the year.' (Khusta, black male)

For Khusta above, the AD programme became an alternatively socially constructed space that allows them to identify one another as marginalised students and to offer support to each other. This is seen in how the 'BComm family' allows them to have access to and to bond with one another as a social capital network.

Although scholars such as Perri 6 (1997:6) refer to Khusta's network as a 'networks of poverty', we argue that such 
networks are important to the entry and the possibilities of surviving $\mathrm{HE}$ for black students as they rely upon one another for familiarity, care and understanding.

For other participants, the AD programme was a spatial institution that constantly Othered them and reminded them that they were black and were 'historically disadvantaged' compared to other 'traditional students' at the university. Lolo reflects on her time in the AD programme:

'I hated it [AD programme]. I used to hate it I never understood. I didn't get it why I was in foundation they gave us the lecture and said it's not a bridging course but a foundation course. Giving it a fancy name does not help and I got 38 point and I need 40 points for mainstream. Foundation is for black people. I've never seen a white person in foundation phase. And I hate the term for 'previously disadvantaged people'. Who said I was previously disadvantaged? What makes me disadvantaged? Because it's nothing but the colour of my skin because I was never disadvantaged. I don't know how apartheid feels because I wasn't there. The foundation programme was tedious. I got bored very quickly. I had a fixed timetable for the whole year. I got bored in three months and I had to stick it through.' (Lolo, black female)

Lolo, in the above quote, offers a sharp critique at the epistemological foundations for $\mathrm{AD}$ as a platform that serves to reinforce their marginality, exclusion and separateness from the broader university community. She asks why the AD programme in her historically white university does not have white students, and is only composed of black students. In her critique of the $\mathrm{AD}$ programme, Lolo goes beyond just the epistemological foundations for the programme, to problematise the notion of 'previously disadvantaged' as epistemically collapsed to refer to black students only. In other words, are there no white students who are also previously disadvantaged and who too could benefit from having access to the AD programme?

Thus, while the AD programme was a useful space for students to identify with one another and establish each other as resourceful forms of capital to each other, for other it was a painful space that raised critical racial questions regarding who belongs in $\mathrm{AD}$, how they are selected and to what extent they help students or reinforce their institutional marginality.

\section{Development or negotiation of habitus}

Maton (2008) argues that the notion of habitus transcends the dichotomies existing between past, present and future, between mind and body, between the social and the individual, between the objective and the subjective and between the voluntarist and the determinist. This means that habitus is a set of assumptions, habits, taken-for-granted ideas and ways of being that students engage with, understand and move on through their academic journey. The development and negotiation or engagement of habitus is the development of an 'endless capacity' to generate thoughts, perceptions, expressions and actions that drive education and enhance performance. It is not the student doing what he or she wants to do, rather he or she is acting according to the level or order of habitus possessed which in itself is a perpetuated and repeated structure inherited or developed from the past and internalised from the objective conditions (Adams 2006). The experiences of the participants of the study best illustrate the workings of habitus and it manifests the presence in AD. Speaking in relation to this, one of the participants pointed out that:

'I remember leaving home I was so nervous because I couldn't come with my parents because of financial reasons. So it was my first time coming to the Eastern Cape, passing Gauteng for that matter. But it was my first time embarking on a longer journey, so I was, I was happy, I was scared you know. And also I needed, even the buses were coming here, people I knew had families with them, they had their parents, so with me it was all sad and all alone. But when I got here, ummm I just felt overwhelmed by everything. I just felt like, I don't belong, you know when you, ummm I had no interaction with anyone by the time. Just looking at the environment and you look at where you come from and who you are, you just feel like, like this can't be me that isn't really me. So it was just that reflective thing that, I just felt like, I didn't belong before I even interacted with anyone else. And not so much because of the negative idea but because I felt so privileged that I just felt like it's not real.' (Mariah, black female)

In the above quotation, Mariah reflects on her fears, frustrations and insecurities when she first came to university. She articulates the anguish of the lack of support that black working-class students often experience when they come to a historically white university and have to negotiate an alienating and marginalising institutional culture (see, e.g. Tabensky \& Matthews 2015; Vincent 2013). Vincent (2013) suggests that in order for us to understand the institutional culture of a university and its effect on those on the margins of HE, we can do so at two levels: at the discursive and at the material level. At the discursive level, these are the 'story stock' that indicate the narrative life and show the habitus of students at the university. Mariah's story above indicates the 'story stock' in feeling overwhelmed 'like I don't belong' indicates the extent to which historically white universities are deeply alienating and marginalising spaces, and programmes such as $\mathrm{AD}$ are there, at least in their formulations, to alleviate that marginality.

Another student, Lungile, credits his close relationship and association with Skey, also in the AD, which enabled him to cope with the challenges at university:

'Skey was also from the bushes when he came here in 2010 both of us had a bit of a connection and we were saying in the same corridor, doing the same subjects. We were pretty much close he was my friend the first person I went to in the morning, we went together to breakfast, lunch, supper in the dining hall, he was someone I able to speak my Xhosa with because you would find other people are Zimbabweans, the white people who spoke English and won't be able to understand Xhosa ... Firstly I saw his attire which meant he was straight out the mountain and that's where I asked him what's happening then he opened up that he's right from the bush and stuff, it was a light conversation and on the same night we went out and that where we actually had a few drinks.' (Lungile, black male) 
In the above quotation, we see an interesting yet complex interplay between social capital and ethnic identity, in how for Lungile and his friend Skey the basis of their social capital network and connection was that that they both had been to the 'mountains'. This refers to the amaXhosa tradition of ulwaluko, that is, male initiation in which young men are inducted into adulthood (see Siswana 2016; Siswana \& Kiguwa 2018).

Language also plays a complex role in the social construction of social capital, in how one's habitus, that is, thoughts, beliefs and identity, can be used through language to reach out and access other connections. This is seen in how for black working-class students in a historically white university, language constitutes a key arena to which the struggle for belonging and identity resides. This is seen with Khusta below, reflecting on such challenges of 'sounding' and speaking English:

'Mdantsane is a place where the only Xhosa people so you would normally communicate in Xhosa and stuff. I'm to express myself in English, which I'm not fluent, in English. yeah I'm not fluent in English and sometimes, I will chill with people, but I won't talk that much because I'm afraid if I say something wrong people might laugh at me or something. Yeah even in my class because I was accepted in BComm accounting. If I question I will not ask in class. I would ask after the lecture and engage and stuff. I won't want ummm English and stuff ... Ummm, it was only that thing with, with the English part, like speaking English all the time that was the most uncomfortable thing cause I was afraid of making mistakes and stuff.' (Khusta, black male)

In the above quotations, Khusta grapples with the challenges of sounding and speaking English, and being afraid of 'making mistakes' in the language. We argue that it is more than language. English becomes the institutional signifier of the university's institutional culture, being and identity, and is one of those spaces that demarcate for black working-class students who belong here, and who do not. Khusta grapples with his challenges by limiting the amount of time he spent speaking the language or associating himself with students who are fluent in the language. This, it could be argued, limits the possibilities for access to richer and much more wellresourced networks and connections.

\section{Conclusion}

South African HE is grappling with the challenges of transformation and decolonisation. While issues of curricula, institutional culture, teaching and learning and others have been theorised and critically engaged with post-2015-2016 student movements, the role that AD plays in helping black working-class students negotiate the terrain of a historically white university remains under-theorised and not sufficiently explored.

Black students in a historically white South African university often go through the AD programme to succeed in these universities. The experiences they have in these universities are unique in themselves and provide insight into the practices of $\mathrm{AD}$ in South African HE and how they navigate the HE landscape. From being on the margins of historically white universities to navigating their way to mainstream universities programmes, these students become accustomed and acculturated with the happenings in the HE setting through the development of different forms of capital and habitus. This acculturation comes at a cost, as it means adopting an assimilationist approach so as to ensure that they not only negotiate the challenges of a historically white university, but that they actually succeed in such an alienating space.

Bourdieu's different forms of capital were useful in helping us think through and conceptualise a historically white university in general and AD in particular, as a field constituting of different actors and agents. While black working-class students' experiences of AD in a white university are complex and contradictory, what was useful about illuminating and shining a spotlight on their experiences, is that it enables the field of AD to move beyond the focus on discourses, phases and logics, and to begin to see the students themselves and how they experience the work of AD. Lolo's insight in questioning the epistemological assumptions of AD work, particularly in racial terms, and also in how students feel secluded and isolated from the broader university community, needs further interrogation and problematising for future research. We thus recommend the following:

- The work of AD in historically white universities needs to be careful in how classes, modules, curriculum, lecture halls and others are established so as to ensure that students in the AD programme do not feel marginalised and separated from the broader university community.

- Careful institutional planning needs to be devised regarding how to tap into the social capital networks and connections that students have formed with one another and the university community, as that is proving critical to how they negotiate their entry, survival and success at university both in $\mathrm{AD}$ and at a historically white university.

- The role of language in general and English in particular as a Eurocentric tool designed to undermine indigenous languages and cultural beliefs is well documented and the critique expansive. Perhaps careful planning within the university management and committees regarding to what extent, following the University of KwaZulu-Natal's approach in moving to a bilingual stance (i.e. isiZulu and English as pedagogical approaches to teaching and learning), could assist black students in the AD programme in historically white universities negotiate the curriculum and understand the material.

\section{Acknowledgements}

The authors would like to thank university students who took part in this study for their assistance in conducting this research.

\section{Competing interests}

The authors have declared that no competing interests exist. 


\section{Author's contributions}

M.N.H. generated the data and wrote the abstract, introduction and literature review. He was also highly engaged in responding to the peer review feedback. K.G.F. helped analyse the data and wrote the theory and conclusion sections.

\section{Funding}

This research received no specific grant from any funding agency in the public, commercial or not-for-profit sectors.

\section{Data availability statement}

Data sharing is not applicable to this article as no new data were created or analysed in this study.

\section{Disclaimer}

The views and opinions expressed in this article are those of the authors and do not necessarily reflect the official policy or position of any affiliated agency of the authors.

\section{References}

Acar, E., 2011, 'Effects of social capital on academic success: A narrative synthesis', Educational Research and Reviews 6(6), 456.

Adams, M., 2006, 'Hybridizing habitus and reflexivity: Towards an understanding of contemporary identity?', Sociology 40(3), 511-528. https://doi.org/10.1177/ 003803850663672

Akoojee, S. \& Nkomo, M., 2007, 'Access and quality in South African higher education: The twin challenges of transformation', South African Journal of Higher Education 21(3), 385-399. https://doi.org/10.4314/sajhe.v21i3.25712

Arbee, A., 2012, 'Knowledge and knowers in the discipline of Marketing at the University of KwaZulu-Natal', PhD thesis, University of KwaZulu-Natal, Durban.

Badat, S., 2009, 'Theorising institutional change: Post-1994 South African higher education', Studies in Higher Education 34(4), 455-467. https://doi.org/10.1080/ 03075070902772026

Badat, S., 2016, 'Deciphering the meanings, and explaining the South African higher education student protests of 2015-16', Pax Academica 1(1), 71-106.

Badat, S. \& Sayed, Y., 2014, 'Post-1994 South African education: The challenge of social justice', The ANNALS of the American Academy of Political and Social Science 652(1), 127-148. https://doi.org/10.1177/0002716213511188

Benson, R., 1999, 'Field theory in comparative context: A new paradigm for media studies', Theory and Society 28(3), 463-498. https://doi.org/10.1023/A:1006982529917

Boughey, C., 2003, 'From equity to efficiency: Access to higher education in South Africa', Arts and Humanities in Higher Education 2(1), 65-71. https://doi.org/10.1177/ 1474022203002001006

Boughey, C., 2007, 'Marrying equity and efficiency: The need for third generation academic development', Perspectives in Education 25(3), 1-11.

Bourdieu, P., 1977, Outline of a theory of practice, Cambridge University Press, Cambridge.

Bourdieu, P., 1984, Distinction: A social critique of the judgement of taste, Harvard University Press, Cambridge.

Bourdieu, P. 1993, The field of cultural production: Essays on art and literature, Columbia University Press, New York.

Bourdieu, P., 2000, Pascalian meditations, Polity Press, Cambridge.

Bourdieu, P., 2003, 'Cultural reproduction and social reproduction', in P. Jarvis \& C. Griffin (eds.), Adult and continuing education: Adult education, viewed from the disciplines, Routledge, New York.

Bourdieu, P., 2011, 'The forms of capital', Cultural Theory: An Anthology 1, 81-93.

Bourdieu, P. \& Johnson, R., 1993, The field of cultural production: Essays on art and literature, Columbia University Press, New York.

Bourdieu, P. \& Wacquant, L.J.D., 1974, An invitation to reflexive sociology, Polity, Cambridge. 1992.

Dhunpath, R. \& Vithal, R., 2014, Alternative access to higher education: Underprepared students or underprepared institutions? Pearson, Cape Town.

Du Bois, W.E.B., 2008, The souls of black folk, Project Gutenberg, Salt Lake City.

Fairclough, N., Jessop, B. \& Sayer, A., 2002, 'Critical realism and semiosis', Alethia 5(1), 2-10. https://doi.org/10.1558/aleth.v5i1.2
Faugier, J. \& Sargeant, M., 1997, 'Sampling hard to reach populations', Journal of Advanced Nursing 26(4), 790-797. https://doi.org/10.1046/j.1365-2648.1997. 00371.x

Foucault, M., 2013, Archaeology of knowledge, Routledge, London and New York.

Fourie, M., 1999, 'Institutional transformation at South African universities: Implications for academic staff', Higher Education 38(3), 275-290. https://doi.org/10.1023/ A:1003768229291

Giloi, S.L., 2015, 'The knowledge-knower structures used in the assessment of graphic design practical work in a multi-campus context', PhD Full thesis, Rhodes University, Grahamstown.

Harker, R., Mahar, C. \& Wilkes, C., 2016, An introduction to the work of Pierre Bourdieu: The practice of theory, Springer, London.

Ihlen, O., 2005, 'The power of social capital: Adapting Bourdieu to the study of public relations', Public Relations Review 31(1), 492-496.

Jansen, J., 2004, 'Changes and continuities in South Africa's higher education system, 1994 to 2004', in L. Chisholm (ed.), Changing class: Education and social change in post-apartheid South Africa, pp. 293-314, HSRC Press, Pretoria.

Jansen, J. \& Motala, S., 2017, Introduction-part I. Curriculum stasis, funding and the "decolonial turn" in universities-inclusion and exclusion in higher education in South Africa', Journal of Education (University of KwaZulu-Natal) 68, 1-2.

Kraak, A.H., 2001, 'Policy ambiguity and slippage: Higher education under new state, 1994-2001', in A.H. Kraak \& M. Young (eds.), Education in retrospect, pp. 85-120, HSRC Publishers, Pretoria.

Levina, N. \& Arriaga, M., 2014, 'Distinction and status production on user-generated content platforms: Using Bourdieu's theory of cultural production to understand social dynamics in online fields', Information Systems Research 25(3), 468-488. https://doi.org/10.1287/isre.2014.0535

Marx, A.W., 1998, Making race and nation: A comparison of South Africa, the United States, and Brazil, Cambridge University Press, Cambridge.

Maton, K., 2005, 'A question of autonomy: Bourdieu's field approach and higher education policy', Journal of Education Policy 20(6), 687-704. https://doi.org/ 10.1080/02680930500238861

Maton, K., 2008, 'Habitus', in M. Grenfell (ed.), Pierre Bourdieu: Key concepts, pp. 49-66, ACUMEN, Stocksfield.

Maton, K., 2013, Knowledge and knowers: Towards a realist sociology of education, Routledge, Oxfordshire.

McKenna, S., 2004, 'The intersection between academic literacies and student identities: Research in higher education', South African Journal of Higher Education 18(3), 269-280. https://doi.org/10.4314/sajhe.v18i3.25496

Muller, J., 2014, 'Every picture tells a story: Epistemological access and knowledge', Education as change 18(2), 255-269. https://doi.org/10.1080/16823206.2014. 932256

Naidoo, R., 2004, 'Fields and institutional strategy: Bourdieu on the relationship between higher education, inequality and society', British Journal of Sociology of Education 25(4), 457-471. https://doi.org/10.1080/0142569042000236952

Neuman, W.L., 2010, Social research methods: Quantitative and qualitative approaches, Pearson Higher Ed., New York, NY.

O'Brien, S. \& O'Fathaigh, M., 2005, 'Bringing in Bourdieu's theory of social capital: Renewing learning partnership approaches to social inclusion', Irish Educational Studies 24(1), 65-76. https://doi.org/10.1080/03323310500184509

Oldfield, S., 2001, 'The South African state in transition: A question of form, function and fragmentation', in E. Motala (ed.), Education and equity: The impact of state policies on South African education, pp. 35-52, Heinemann, Cape Town.

Palys, T., 2008, 'Basic research', in L.M. Given (ed.), The Sage encyclopedia of qualitative research methods, pp. 58-60, Sage, Los Angeles, London, New Delhi, Singapore.

Pavlich, G. \& Orkin, M., 1993, Diversity and quality: Academic development at South African tertiary institutions: A comparative case study conducted by CASE for the Ford Foundation, Department of Education, Pretoria

Perri 6, 1997, Holistic government, Demos, London.

Prinsloo, E.H., 2016, 'The role of the humanities in decolonising the academy', Arts and Humanities in Higher Education 15(1), 164-168. https://doi.org/10.1177/ 1474022215613608

Putnam, R.D., 1995, 'Bowling alone: America's declining social capital', Journal of Democracy 6(1), 65-78. https://doi.org/10.1353/jod.1995.0002

Putnam, R.D., 2000, 'Bowling alone: America's declining social capital', in L. Crothers \& C. Lockhart (eds.), Culture and politics, pp. 223-234, Palgrave Macmillan, New York.

Puwar, N., 2004, Space invaders: Race, gender and bodies out of place, Berg, Oxford.

Seidman, I., 2006, Interviewing as qualitative research: A guide for researchers in education and the social science, Teachers College Press, New York.

Sennett, J., Finchilescu, G., Gibson, K. \& Strauss, R., 2003, 'Adjustment of black students at a historically white South African university', Educational Psychology 23(1), 107-116. https://doi.org/10.1080/01443410303219

Shammas, V.L. \& Sandberg, S., 2016, 'Habitus, capital, and conflict: Bringing Bourdieusian field theory to criminology', Criminology \& Criminal Justice 16(2), 195-213. https://doi.org/10.1177/1748895815603774

Shawa, L.B., 2015, 'Graduate output in South African higher education', paper presented at the University of KwaZulu-Natal's 9th annual teaching and learning in higher education conference 2015, Durban, KwaZulu-Natal, South Africa, 21-23rd September, pp. 187-197. 
Siswana, A., 2016, 'Ulwaluko kwa Xhosa: Young Xhosa men's lived experiences in the context of traditional male initiation', Unpublished Master's thesis, Rhodes University, Grahamstown.

Siswana, A. \& Kiguwa, P., 2018, 'Social media representations of masculinity and culture in Inxeba (The Wound)', Agenda: Empowering women for gender equity 32(3), 53-61. https://doi.org/10.1080/10130950.2018.1485290

Tabensky, P. \& Matthews, S., 2015, Being at home - Race, institutional culture and transformation at South African higher education institutions, UKZN Press, Pietermaritzburg.

Vincent, L., 2008, 'The limitations of "inter-racial contact": Stories from young South Africa', Ethnic and Racial Studies 31(8), 1426-1451. https://doi.org/ 10.1080/01419870701711839
Vincent, L., 2013, 'Changing a university's institutional culture', paper presented at the Higher Education of South Africa Colloquium on Transformation, Bloemfontein, South Africa, May 6.

Vincent, L. \& Hlatshwayo, M., 2018, 'Ties that bind: The ambiguous role played by social capital in black working class first-generation South African students' negotiation of university life', South African Journal of Higher Education 32(3), 118-138.

Vorster, J.-A. \& Quinn, L., 2017, 'The "decolonial turn": What does it mean for academic staff development?' Education as Change 21(1), 31-49. https://doi.org/ $10.17159 / 1947-9417 / 2017 / 853$

Yang, Y., 2014, 'Bourdieu, practice and change: Beyond the criticism of determinism' Educational Philosophy and Theory 46(14), 1522-1540. https://doi.org/10.1080/ 00131857.2013 .839375 